\title{
Ovarian gonadotrophin surge-attenuating factor (GnSAF): where are we after 20 years of research?
}

\author{
Paul A. Fowler ${ }^{1}$, Tarja Sorsa-Leslie ${ }^{1,2}$, William Harris ${ }^{2}$ and Helen D. Mason ${ }^{3}$ \\ ${ }^{1}$ Department of Obstetrics and Gynaecology and ${ }^{2}$ Department of Molecular and Cell Biology, \\ University of Aberdeen, Aberdeen AB25 2ZD, UK; and ${ }^{3}$ Departments of Obstetrics and Gynaecology, \\ and Biomedical Sciences, St George's Hospital Medical School, London SW17 ORE, UK
}

\begin{abstract}
When gonadotrophin-stimulated IVF methods were being developed in the 1970s and 1980s, understanding of the physiology of FSH improved. In addition to its classic actions of stimulating aromatase activity and oestradiol secretion by ovarian granulosa cells, FSH was found to stimulate the ovarian production of an uncharacterized hormone known by its specific effect of reducing pituitary responsiveness to $\mathrm{GnRH}$. This hormone has been called gonadotrophin surge-attenuating factor (GnSAF), gonadotropin surge-inhibiting factor (GnSIF), various abbreviations (GnSAF/IF, GnSIF/AF) and also attenuin. Although first described in the 1980s, GnSAF has still not been convincingly characterized and no published candidate amino acid sequences conclusively relate to GnSAF bioactivity. On the basis of superovulation studies and in vitro experimentation into the roles of steroids in regulating $\mathrm{LH}, \mathrm{GnRH}$ and $\mathrm{GnRH}$ self-priming, the concept that GnSAF has a role in the regulation of $\mathrm{LH}$ secretion, the timing of the $\mathrm{LH}$ surge and the prevention of premature luteinization developed. For at least a decade, understanding of the specific GnSAF effects of reducing pituitary sensitivity to $\mathrm{GnRH}$, especially $\mathrm{GnRH}$ self-priming and antagonizing the stimulatory effects of oestradiol on $\mathrm{GnRH}$-induced $\mathrm{LH}$ secretion, supported this concept. However, improved knowledge of the changes in GnSAF bioactivity in follicular fluid and serum in women requires revision of this concept. The present authors propose that the main role of GnSAF is probably the negative regulation of pulsatile $\mathrm{LH}$ secretion, mainly during the first half of the follicular phase, indicating a critical role in the regulation of folliculogenesis and oestradiol secretion.
\end{abstract}

Evidence for an ovarian factor that reduced $\mathrm{GnRH}$ induced $\mathrm{LH}$ secretion dates back to the late 1970s when de Jong et al. (1979) reported a $<10 \mathrm{kDa}$ fraction of ethanol-extracted bovine follicular fluid (bFF) which reduced pituitary $\mathrm{LH}$ release. By the second half of the 1980s it was clear from the existing data that FSH treatment of women, monkeys and rats stimulated the production of an unidentified, non-steroidal factor. This factor was named gonadotrophin surge-inhibiting factor (GnSIF) or gonadotrophin surge-attenuating factor (GnSAF) (Ferraretti et al., 1983; Littman and Hodgen, 1984; Sopelak and Hodgen, 1984; Messinis and Templeton, 1986). Schenken et al. (1984) showed that when monkeys were superovulated, serum collected from the ovarian vein inhibited the responsiveness of cultured rat pituitary cells to $\mathrm{GnRH}$, the first clear evidence that GnSAF is an ovarian product. However, ovarian vein serum and follicular fluid normally contain

Email: p.a.fowler@abdn.ac.uk high concentrations of sex steroids, especially oestradiol. Therefore, when trying to characterize this activity many researchers used charcoal extraction of a wide range of body fluids before bioassay for GnSAF using rat or sheep pituitary cells or perifused fragments. Thus GnSAF bioactivity has been detected in steroid-free serum and follicular fluid or ovarian extracts from superovulated and spontaneously cyclic women, cows, pigs and rats and from testis extract and Sertoli cell-conditioned medium (Fowler et al., 1990, 1994a, 1995; Koppenaal, et al., 1993; Kita et al., 1994; Tio et al., 1994; Danforth et al., 1987; van Dieten et al., 1999). Nevertheless, although GnSAF bioactivity could not be steroidal in nature, it remained to be demonstrated that the activity was not due to inhibin. Whereas inhibin had suppressive effects on $\mathrm{GnRH}$-induced $\mathrm{LH}$ secretion at high concentrations in the rat pituitary (Farnworth et al., 1988), this was not the case in the ovine pituitary where inhibin stimulated GnRH-induced LH secretion (Muttukrishna and Knight, 1990). Therefore, as steroid-free human follicular fluid inhibits $\mathrm{GnRH}$-induced $\mathrm{LH}$ secretion from both rat and 
sheep pituitaries (Fowler et al., 1994b), GnSAF cannot be due to inhibin. This conclusion is reinforced by the fact that co-incubation of human follicular fluid with inhibin antiserum has no effect on GnSAF bioactivity, as shown by continued reduction of $\mathrm{GnRH}$-induced $\mathrm{LH}$ secretion, despite blocking the specific inhibin bioactivity of suppressing basal FSH secretion (Byrne et al., 1995).

From the evidence for the existence of GnSAF it is clear that production of this hormone is regulated by FSH. The data supporting this are summarized in Fig. 1. Data obtained from in vivo studies after the administration of a single FSH injection to women (Fig. 1a) or multiple FSH injections to cows (Fig. 1b) as well as in vitro data based on granulosa cells from spontaneously cyclic women (Fig. 1c) are shown. GnSAF bioactivity in women (Messinis et al., 1991, 1993a, 1994a) was calculated from measurements of circulating LH concentrations in response to $\mathrm{GnRH}$ injections, reduced $\mathrm{LH}$ secretion reflecting increased circulating GnSAF. GnSAF bioactivity in cows (Fowler and Price, 1997) was calculated by in vitro bioassay of serial blood samples. The bioassay depends upon the specific GnSAF effect of reducing $\mathrm{GnRH}$-induced $\mathrm{LH}$ secretion, but not basal gonadotrophin release from cultured rat anterior pituitary cells. After the onset of $\mathrm{FSH}$ treatment in both women and cows, GnSAF bioactivity increased more rapidly than either oestradiol or inhibin. However, in post-menopausal women (Messinis et al., 1994b) FSH treatment did not stimulate GnSAF activity. LH pulse amplitude and frequency were reduced after $20 \mathrm{~h}$ (Gosselin et al., 2000) in FSH-treated cows, the former indicating increased GnSAF bioactivity in vivo. The stimulation of other candidate hormones for suppression of GnRH-induced LH secretion, that is oestradiol, inhibin A and inhibin B, was markedly slower than the stimulation of GnSAF (Messinis et al., 1991, 1993a, 1994a; Fowler and Price, 1997; Burger et al., 1998; Gosselin et al., 2000; Welt et al., 2001). Whether GnSAF acts on the hypothalamus directly, in this instance to affect GnRH pulse frequency, is unknown but is unlikely if $\mathrm{GnSAF}$ is about $60-70 \mathrm{kDa}$. However, by reducing LH pulse amplitude, GnSAF could reduce the number of apparent LH pulses detected.

The time course of stimulation of GnSAF bioactivity from the cultured human granulosa cells collected from small $(6-9 \mathrm{~mm})$ follicles was rapid (Fowler and Mason, 2000; Fig. 1c), supporting the observation of detectable GnSAF bioactivity in vivo within $8 \mathrm{~h}$ of a single $\mathrm{FSH}$ injection in women. It is noteworthy that the stimulation of GnSAF bioactivity in vitro occurred in the absence of androgen substrate for the granulosa cells, preventing these cells from manufacturing significant amounts of oestradiol in response to FSH treatment. Western blotting of the proteins secreted by these granulosa cells with a rat polyclonal antiserum with demonstrable GnSAFblocking effects (Fowler et al., 2002) showed upregulated expression of a number of proteins after $5 \mathrm{~h}$ exposure of the cells to FSH (Fowler and Mason, 2000). In a similar way, when medium conditioned by granulosa cells and theca and stromal tissues was added to a rat pituitary cell bioassay, GnSAF bioactivity was present only in granulosa cell-conditioned medium (Fowler et al., 2002).

It is now clear that GnSAF bioactivity is not a result of inhibin $A$, inhibin $B$, oestradiol, progesterone or any other steroid hormone and is an FSH-stimulated ovarian product, originating specifically from the granulosa cell.

\section{Current status of GnSAF characterization}

A detailed examination of purification strategies for GnSAF is given in Fowler and Templeton (1996). Here this review will discuss the status of biochemical knowledge of GnSAF. To date there have been five main published attempts to characterize GnSAF, yielding amino acid sequences on four occasions, as shown in Table 1. Unfortunately, the collaborative purification attempt by the Danforth and Fowler groups (Mroueh et al., 1996) obtained insufficient protein for Edman sequencing. This is one of the problems that has slowed progress on the identification of GnSAF: very small quantities of bioactive material after purification strategies. Despite the efforts made, not one of the sequences in Table 1 has been conclusively demonstrated as constituting the amino acid sequence for GnSAF bioactivity. Furthermore, when protein sequence matches have been taken from online databases, the candidate proteins do not match mass or isolectic point $(\mathrm{pl})$ values obtained for GnSAF and are not known to have the ability to suppress GnRH-induced LH secretion (Fowler et al., 2002).

The major problems with purification of GnSAF have been its co-elution with serum albumin and IgGs, and the fact that despite marked GnSAF bioactivity in a number of biological fluids, the protein appears to be present at low concentrations. The fact that the protein is present at low concentrations makes it difficult for sufficient bioactive material to be obtained for Edman sequencing. Indeed, several sequencing attempts have resulted in the identification of serum albumin and heavy chain IgGs despite numerous steps, such as blue dye affinity chromatography to reduce serum albumin contamination (P. A. Fowler, H. D. Mason, W. T. Melvin, B. Byrne, Y. Wilson, P. Cash, T. Sorsa-Leslie, L. Cowking, R. Bates and W. Harris, unpublished observations, 1990-1999).

The latest published purification procedure has sidestepped some of the problems previously encountered, by using a serum and BSA-free granulosa-luteal cell culture system (Fowler et al., 2002). The authors found that human ovarian GnSAF bioactivity was associated with proteins of approximately $64 \mathrm{kDa}$ and a pl of 5.7$5.8 \mathrm{pH}$. These values are in agreement with those of Danforth and Cheng (1995) and Mroueh et al. (1996), but are not in agreement with those of Tio et al. (1994), 
(a) In vivo production of GnSAF: women

(b) In vivo production of GnSAF: cows

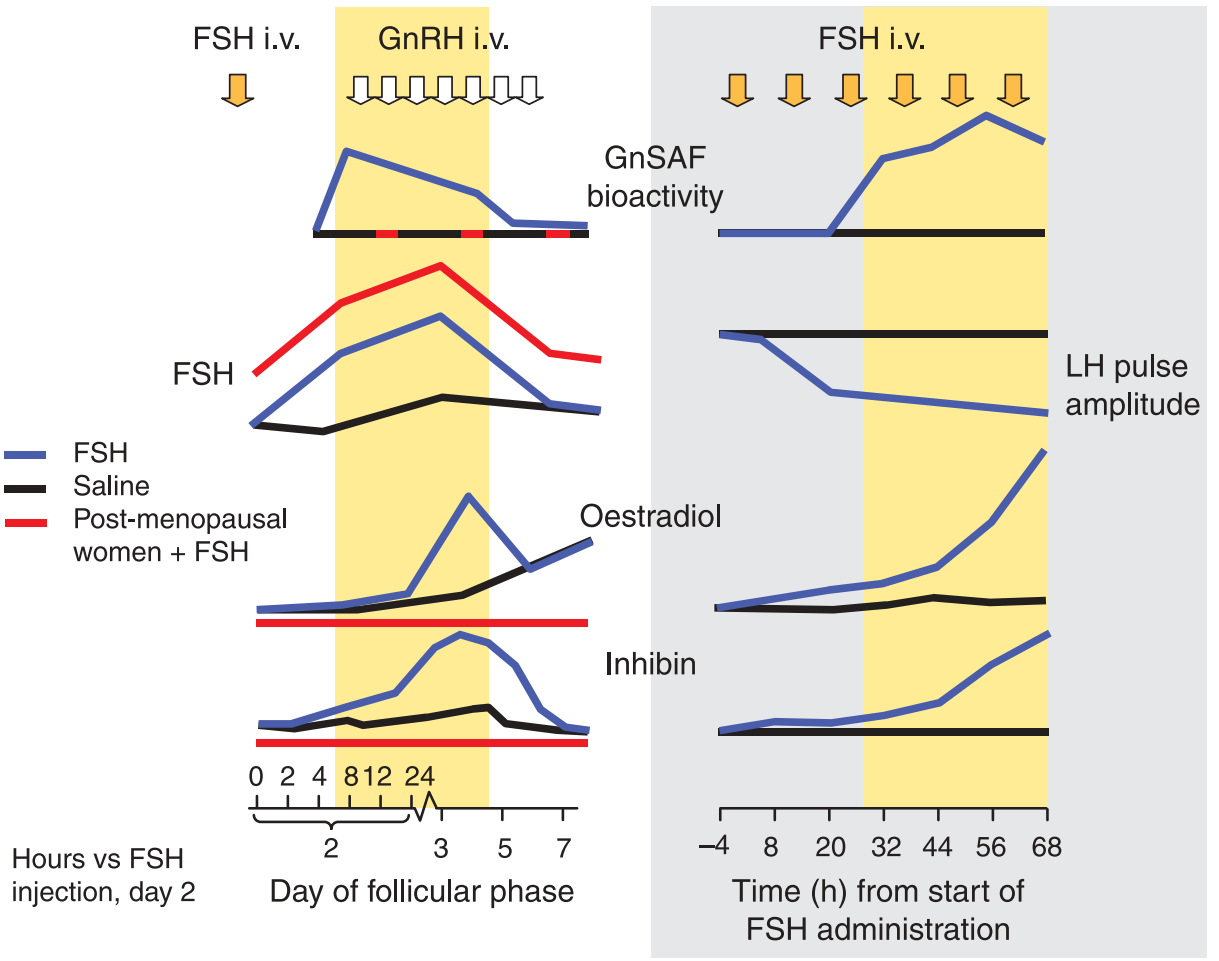

(c) In vitro production of GnSAF: human granulosa cells

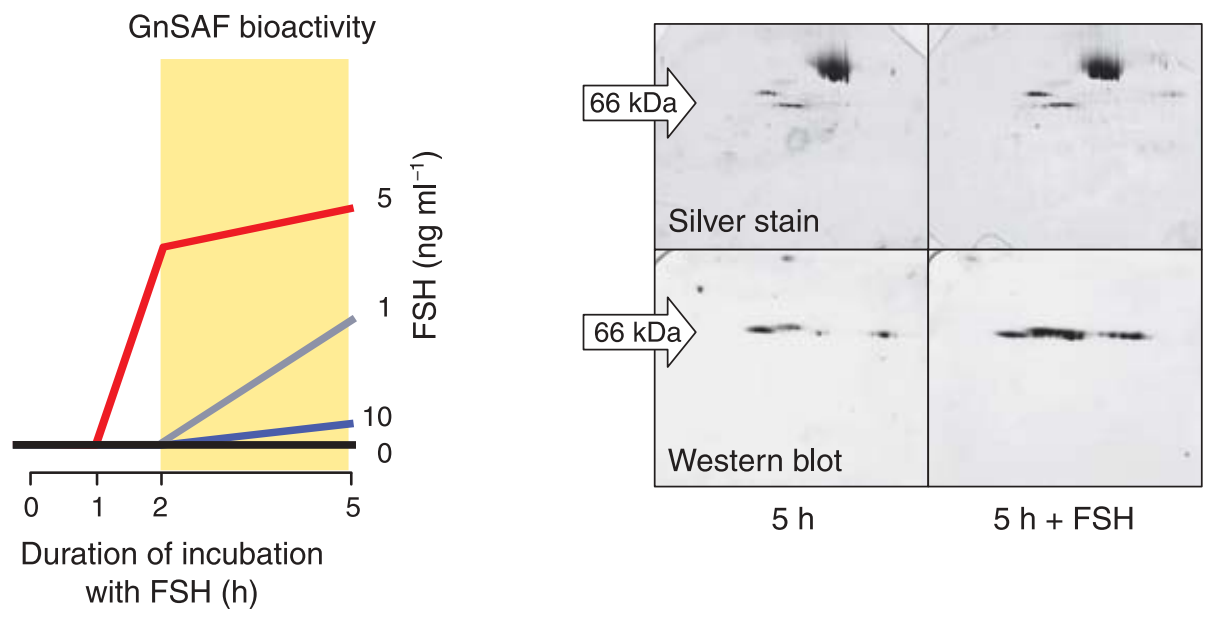

Fig. 1. The stimulation of gonadotrophin surge-attenuating factor (GnSAF) bioactivity by FSH both in vivo in (a) normally cyclic and post-menopausal women; (b) dairy cows; and (c) in vitro from granulosa cells collected from 6-9 mm follicles in spontaneously cyclic women. The periods of increased GnSAF are shown by vertical yellow bars. In women (a) day 2 of the follicular phase is subdivided (see italicized text above the horizontal axis) into hours relative to a single injection of $\mathrm{FSH}$ at $0 \mathrm{~h}$, with $\mathrm{GnRH}$ challenges shown between day 2 and day 6 of the follicular phase. The days of the treatment period are shown in normal font below the horizontal axis. In cows (b) time points are shown relative to the first FSH injection at $0 \mathrm{~h}$. FSH injections were repeated every $12 \mathrm{~h}$. For the in vitro data (c) time points are shown relative to the addition of FSH to the culture wells at $0 \mathrm{~h}$. Proteins secreted by the granulosa cells cultured in vitro in the presence and absence of FSH are shown in the form of silver-stained two-dimensional gels (upper gel pair) and western blot (lower gel pair) using a rat polyclonal antibody which blocks GnSAF bioactivity in vitro (Fowler et al., 2002). Both show FSH-induced upregulation of protein at 60-70 kDa. 
Table 1. Candidate gonadotrophin surge-attenuating factor (GnSAF) sequences

\begin{tabular}{|c|c|c|c|c|}
\hline Molecular weight (kDa) & Amino acid sequence & Source & Species & Reference \\
\hline 37.0 & $\begin{array}{l}\mathrm{NH}_{2}: \text { SDXXPQL } \\
\text { No clear identification }\end{array}$ & $\begin{array}{l}\text { Sertoli cell-conditioned } \\
\text { medium }\end{array}$ & Rat & Tio et al., 1994 \\
\hline 69.0 & $\begin{array}{l}\mathrm{NH}_{2}: \text { KPLAE } \\
\text { No clear identification }\end{array}$ & Follicular fluid & Pig & Danforth and Cheng, 1995 \\
\hline 63.0 & ? No clear identification & Superovulated follicular fluid & Human & Mroueh et al., 1996 \\
\hline 12.5 & $\begin{array}{l}\text { COOH:ALEVDETYVPK } \\
\text { Identification: truncated C-terminus } \\
\text { of serum albumin }\end{array}$ & Superovulated follicular fluid & Human & Pappa et al., 1999 \\
\hline 64.0 & $\begin{array}{l}\text { Internal: EPQVYVHAP } \\
\text { No clear identification }\end{array}$ & $\begin{array}{l}\text { Granulosa-luteal } \\
\text { cell-conditioned medium }\end{array}$ & Human & Fowler et al., 2002 \\
\hline 64.0 & $\begin{array}{l}\mathrm{NH}_{2} \text { : XVPQGNAXXN } \\
\text { No clear identification }\end{array}$ & & & \\
\hline
\end{tabular}

or Pappa et al. (1999). Fowler et al. (2002) found that a $17 \mathrm{kDa}$ fraction of human granulosa-luteal cellconditioned medium caused minor reduction in $\mathrm{GnRH}$ induced $\mathrm{LH}$ secretion from rat gonadotrophs, despite the main GnSAF bioactivity occurring at $64 \mathrm{kDa}$. This is similar to the $12.5 \mathrm{kDa}$ activity reported by Pappa et al. (1999). However, in contrast to Pappa et al. (1999) who suggest that GnSAF is a truncated part of the C-terminus of serum albumin, Fowler and Danforth have not reported GnSAF bioactivity to be bound to serum albumin affinity chromatography steps. The activity reported at $37 \mathrm{kDa}$ by Tio et al. (1994) used conditioned medium from Sertoli cells rather than granulosa-luteal cells. Again in contrast to findings by other groups (Danforth and Cheng, 1995; Mroueh et al., 1996; Pappa et al., 1999; Fowler et al., 2002), purified material prepared by Tio et al. (1994) retained inhibin-like bioactivity as it caused a reduction in basal $\mathrm{FSH}$ secretion from rat pituitary cultures, indicating that the bioactivity is probably not GnSAF, but possibly a male homologue.

The internal and $\mathrm{N}$-terminal amino acid sequences reported by Fowler et al. (2002) may be part of the same protein, but neither matches the other published putative GnSAF sequences (Tio et al., 1994; Danforth and Cheng, 1995; Pappa et al., 1999). Furthermore, no common proteins yet identified contain combinations of the five candidate GnSAF amino acid sequences. However, it is entirely possible that when GnSAF is finally convincingly sequenced, one or more of these putative sequences may prove to have been part of the bioactive molecule.

The current GnSAF purification strategy in our research group involves the use of phage display antibody libraries to circumvent the problems encountered by all groups attempting to purify GnSAF by conventional means. Sorsa-Leslie et al. (2001, 2002) have successfully used phage display techniques to produce antibodies against partially purified human granulosa-luteal cellconditioned medium. Three of these antibodies were found to block the effects of human GnSAF on GnRHinduced LH secretion from rat pituitary cell cultures. The phage display-derived antibodies also appear to be suitable for immunopurification of GnSAF and have been engineered into human IgGs in order to scaleup the immunopurification process. Both the phage antibodies (Sorsa-Leslie et al., 2003) and the anti-GnSAF rat polyclonal antiserum reported by Fowler et al. (2002) have been used for the successful immunopurification of GnSAF bioactivity and the purified preparations are currently being used for sequencing experiments. It may be therefore that GnSAF is on the point of being convincingly characterized.

\section{GnSAF in women}

\section{GnSAF in the follicle}

The production of GnSAF in the ovarian follicle is clearly related to follicle size in both stimulated and spontaneous cycles, and follicular fluid from follicles $<11 \mathrm{~mm}$ (stimulated cycles, Fowler et al., 1994b) or 6$8 \mathrm{~mm}$ (spontaneous cycles, Fowler et al., 2001) contain the greatest amount of GnSAF bioactivity. This is shown in Fig. 2, which clearly demonstrates a lack of either positive or negative correlation between follicular fluid GnSAF bioactivity and follicular fluid concentrations of inhibin A, inhibin B, oestradiol or progesterone (McNatty, 1981; Westergaard et al., 1986; Fowler et al., 1994b, 2001; Magoffin and Jakimuik, 1997). The same holds true for activin (Fowler et al., 2001). In a similar way, small follicles in pig ovaries contain the highest concentrations of GnSAF, with bioactivity falling sharply in preovulatory follicles in particular (Kita et al., 1994). These findings demonstrate that GnSAF is primarily produced by small growing follicles.

\section{GnSAF in the circulation}

An important clue to the physiological roles of many hormones is the pattern of changes in their concentration in the peripheral circulation. For GnSAF, certain changes in serum concentrations, such as a fall before the $\mathrm{LH}$ surge, would be essential to support the hypothesis that 
(a) Spontaneous cycle

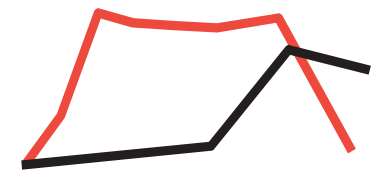

(b) Stimulated cycle

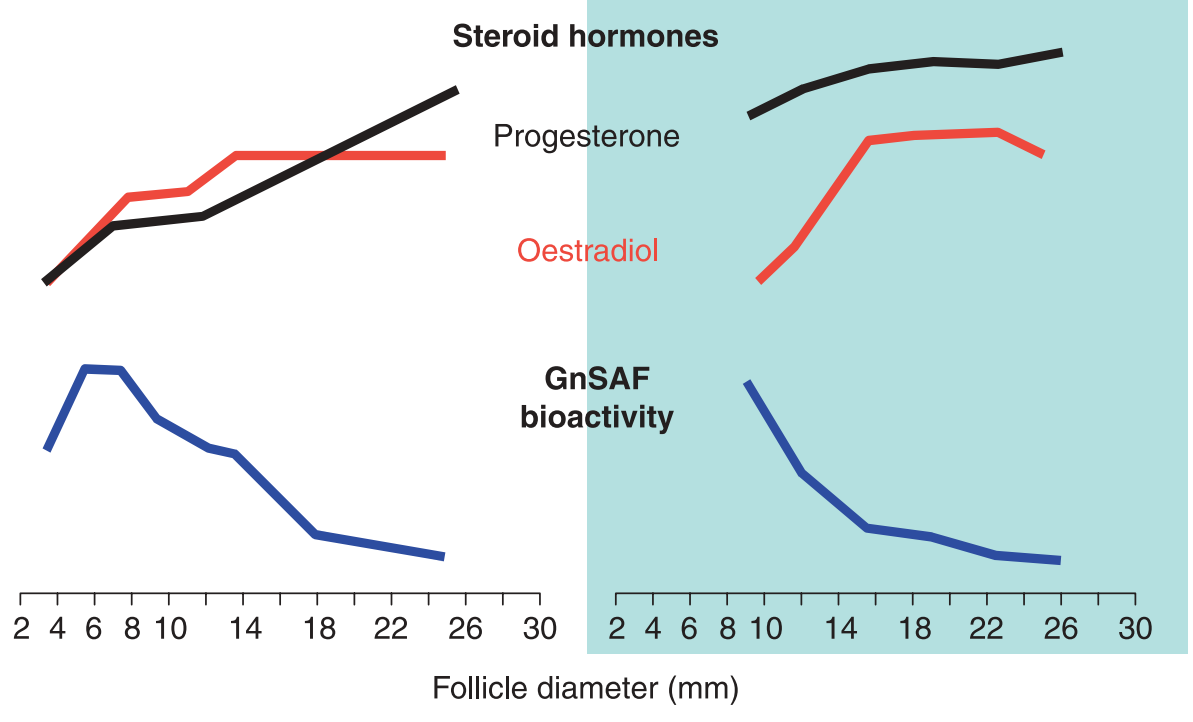

Fig. 2. Human follicular fluid gonadotrophin surge-attenuating factor (GnSAF) bioactivity is greatest in small follicles whether collected from (a) spontaneous or (b) stimulated cycles. In both types of cycle follicular fluid GnSAF content is related to follicle size, with GnSAF production decreasing with increasing follicle diameter. Note that concentrations of steroid hormones and the inhibins in follicular fluid are known to be extremely variable and only general trends are shown in this diagram.

it has a role in the regulation of the timing and magnitude of the LH surge. However, whereas GnSAF bioactivity is readily measurable in serum from women undergoing ovarian stimulation for IVF, the detection of GnSAF in serum from spontaneously cyclic women has proved more difficult. It is predictable that as $\mathrm{FSH}$-stimulated women have reduced responsiveness to $\mathrm{GnRH}$, their circulating GnSAF titres would be higher than those of untreated women. Nevertheless, this slowed attempts to determine the GnSAF concentrations in the serum of spontaneously cyclic women throughout the menstrual cycle. Byrne et al. (1993) concentrated serum from spontaneously cyclic women tenfold before bioassay and found that GnSAF bioactivity was low early in the follicular phase, peaked in the mid-follicular phase and then declined in the late follicular phase.

Improvements to the GnSAF bioassay developed by our group allowed the detection of GnSAF bioactivity in unprocessed serum from spontaneously cyclic women (Martinez et al., 2002). These data, combined with the data from Byrne et al. (1993) are shown in Fig. 3. As expected, GnSAF decreases as the number of small follicles declines after follicular dominance is established. The corpus luteum does not appear to produce GnSAF in women, but small developing follicles may produce GnSAF during the luteal phase (Messinis et al., 1996). Furthermore, decreasing pituitary responsiveness to $\mathrm{GnRH}$ during the luteal-follicular transition indicates that small follicles, responding to the luteal-follicular FSH rise, may be producing GnSAF bioactivity at the end of the luteal phase (Messinis et al., 1993b). Certainly, by very early in the follicular phase GnSAF bioactivity is high in the circulation (Martinez et al., 2002). Overall, the circulating profiles of inhibin A, inhibin B, oestradiol and progesterone, derived from a number of studies including Groome et al. (1996), do not explain the in vivo and in vitro bioassay data upon which the proposed pattern of GnSAF concentrations in the peripheral circulation of women is based.

The emergence of new data supporting earlier suggestions of the occurrence of follicular waves in women during the follicular phase (Baerwald et al., 2003a,b) 


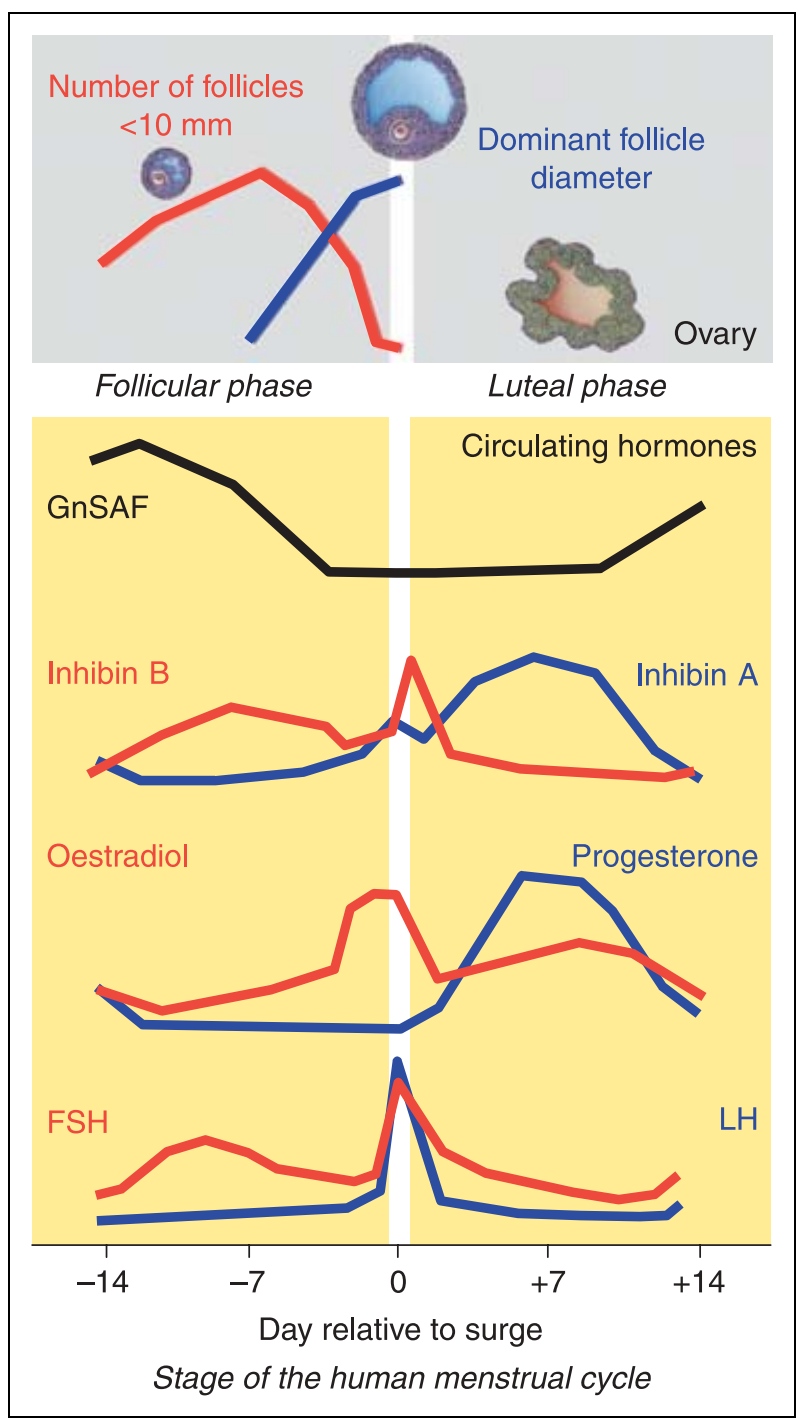

Fig. 3. Gonadotrophin surge-attenuating factor (GnSAF) in relation to the menstrual cycle. Data on GnSAF bioactivity is predominantly derived from studies based on the present authors' in vitro rat pituitary cell bioassay for GnSAF using serum from spontaneously cyclic women, and on in vivo studies of $\mathrm{LH}$ responses to $\mathrm{GnRH}$ in women. Circulating GnSAF peaks during the early-mid-follicular phase, is low during the mid-late follicular and most of the luteal phases, probably increasing with renewed follicular development driven by the inter-cycle FSH rise.

has the implication that the pattern of circulating GnSAF concentrations presented in this review may be subject to at least some modification once a more sensitive means of GnSAF detection, such as an immunoassay, has been developed.

\section{A role for GnSAF in the endocrine regulation of the menstrual cycle?}

In women, the cyclic changes in gonadotrophins drive ovarian function and are regulated by feedback from the ovary on the hypothalamus-pituitary functional unit (reviewed by Chabbert Buffet et al., 1998).

\section{Inter-cycle FSH rise}

For much of the luteal phase the hypothalamus and pituitary are 'clamped' in a state of reduced activity as far as gonadotrophin secretion is concerned. However, towards the end of the luteal phase the function of the corpus luteum deteriorates, oestradiol, progesterone and inhibin A begin to decrease and the pituitary undergoes a rebound, resulting in the inter-cycle FSH rise. The signal drives recruitment of a cohort of small follicles which undergo a final development phase.

\section{Oestradiol and inhibin B}

As they grow, the small follicles secrete increasing quantities of inhibin B, peaking at about day 8 of the follicular phase. In a similar way, early in the follicular phase the growing follicles produce small quantities of oestradiol, which has a negative feedback effect on LH secretion via hypothalamic sites of action. The inhibin B has a negative feedback effect on FSH which then begins to decrease. Whereas there are ample data indicating that oestradiol suppresses FSH secretion (for example Bassett and Zeleznik, 1990), recent studies indicate that in women the inhibins play a major role in the suppression of $\mathrm{FSH}$ as the follicular phase progresses (Welt et al., 2003). In these studies the importance of oestradiol in the negative regulation of $\mathrm{FSH}$ is mainly via a hypothalamic action. However, several studies, as reviewed by Zeleznik and Benyo (1994), support the concept that oestradiol is a significant factor regulating the reduction in circulating FSH during the mid-late follicular phase.

Whether due to inhibin B or oestradiol, FSH decreases and only the dominant follicle survives the loss of FSH support and this undergoes explosive growth, supported by the low circulating titres of LH (Sullivan et al., 1999). It is important that during the follicular phase inhibin B production by smaller follicles is primarily stimulated by $\mathrm{FSH}$ whereas $\mathrm{LH}$ stimulates inhibin A production from more mature follicles (Welt et al., 2001).

As the follicles grow, oestradiol titres increase and oestradiol secretion from the dominant follicle increases exponentially in the last few days of the follicular phase. During this stage, the feedback effect of oestradiol switches from negative to positive, acting as a powerful signal to both hypothalamus and pituitary to produce the GnRH and LH surges.

\section{GnRH pulses, the GnRH surge and GnRH self-priming}

Unlike in many other species, including non-human primates (Pau et al., 1993), there is no direct evidence for a preovulatory $\mathrm{GnRH}$ surge in women. A recent review 
(Park et al., 2002) assessed the evidence from a number of studies during the 1970s and 1980s for increased GnRH pulse frequency during the periovulatory period, on the basis of LH pulses. However, there is also experimental evidence that $\mathrm{GnRH}$ is reduced at the time of the human LH surge (Martin et al., 1998). The role of progesterone should not be ignored and McCartney et al. (2002) indicated that increasing $\mathrm{GnRH}$ pulse frequency in the course of the follicular phase partly reflects the declining effects of negative feedback actions of luteal phase progesterone, a conclusion supported by Skinner et al. (2000). Whether or not there is a periovulatory GnRH surge in humans, the patterns of hypothalamic $\mathrm{GnRH}$ production are known to be important in the regulation of gonadotrophin secretion because abnormal GnRH pulse patterns are associated with a range of reproductive dysfunctions (Marshall et al., 2001). If GnRH pulses are sufficiently frequent, especially after a few days of increased oestradiol, then $\mathrm{GnRH}$ self-priming occurs. Self-priming, or self-potentiation, is the phenomenon whereby a subsequent $\mathrm{GnRH}$ pulse stimulates a larger LH pulse from the pituitary than the preceding GnRH pulse: the pituitary $\mathrm{GnRH}$ receptors become 'primed'. The exact role of self-priming in the generation of the $\mathrm{LH}$ surge is debatable. In a recent review, de Koning et al. (2001) concluded that low or absent negative feedback by GnSAF contributed to increased LH secretion during the periovulatory period rather than this being due to increased $\mathrm{GnRH}$ effects via self-priming.

\section{The puzzle}

The switching of oestradiol feedback from negative to positive and back to negative during the menstrual cycle and the fact that overt $\mathrm{GnRH}$ self-priming is limited to the periovulatory period remain incompletely understood. If steroid hormones alone are responsible for the LH surge, then reproducing mid-cycle steroid concentrations in women or monkeys should result in a normal LH surge. Characteristically, the LH surge that results is reduced in amplitude but nevertheless very clear (Yamaji et al., 1971; Taylor et al., 1995). However, these studies involve either (1) ovariectomized monkeys which would therefore have no circulating GnSAF; or (2) women administered late follicular phase steroids during the early-mid follicular phase. In this case the secretion of $\mathrm{LH}$ (82.7 iu I $\mathrm{I}^{-1}$ with oestradiol alone and $69.7 \mathrm{iu} \mathrm{I}^{-1}$ with oestradiol and progesterone versus $121.7 \mathrm{iu} \mathrm{I}^{-1}$ in normal controls) is clearly reduced but not abolished. This effect is probably due to the fact that higher (mid-follicular phase) concentrations of GnSAF would be present than would be seen during the normal late follicular phase. Therefore, the result would be that sufficient GnSAF would be present to antagonize the effects of the steroids. However, in studies in non-ovariectomized monkeys (Karsch et al., 1973), the administration of high concentrations of oestradiol, similar to those seen in periovulatory animals, stimulated LH surges in half the monkeys after $36 \mathrm{~h}$ exposure in the early follicular phase. It may be that during this $36 \mathrm{~h}$ period the exogenous oestradiol reduces $\mathrm{FSH}$ concentration and the population of small follicles exhibits a declining production of GnSAF. Oestradiol could then overcome the inhibitory effects of GnSAF, a possibility highlighted by the way in which supraphysiological concentrations of oestradiol induced LH surges after only $24 \mathrm{~h}$ exposure.

In summary, overall these data indicate that steroids alone do not explain the control of the LH surge although high concentrations of oestradiol stimulate the occurrence of the LH surge. However, the fact that GnSAF bioactivity has been observed below the level of detection in the present authors' bioassay in women during the late follicular phase (Martinez et al., 2002) indicates that there would be very little or no GnSAF to antagonize oestradiol-positive feedback or GnRH selfpriming during the periovulatory period. However, a study in sheep (Clarke, 1995) concluded that the increase in pituitary responsiveness to $\mathrm{GnRH}$ at the time of the LH surge was caused by the disappearance of an inhibitory signal that was not steroidal in nature, and which preceded any increase in $\mathrm{GnRH}$ release. This primary role of oestrogen in stimulating the $\mathrm{LH}$ surge has been a feature of reviews on this topic for some time (for example Shoham et al., 1995) and is based on work such as that by Knobil's group (Ordog et al., 1998) who have shown that oestradiol has undoubted positive feedback effects on LH secretion, rather than merely negative effects. However, even in post-menopausal women, exogenous oestradiol and progesterone retained some negative feedback effects on LH secretion (Gill et al., 2002). It was unfortunate that the authors did not also perform $\mathrm{GnRH}$ challenges. Given the well-known critical functions of steroids in regulating the LH surge, an interesting possibility is a possible role for GnSAF in regulating follicular steroidogenesis by reducing $\mathrm{LH}$ pulse amplitude. In cows for instance, increased $\mathrm{LH}$ and subsequently oestradiol is associated with subsequent follicular deviation to dominance (reviewed by Ginther et al., 2001). Therefore, rather than regulating the timing of the LH surge by directly reducing pituitary responsiveness to $\mathrm{GnRH}$, GnSAF may have a role in regulating the timing of the $\mathrm{LH}$ surge by regulating follicular phase $\mathrm{LH}$ pulse amplitude and therefore playing a role in the control of oestradiol secretion.

Whereas oestradiol potentiates the suppressive effects of GnSAF on GnRH-induced LH secretion (P. A. Fowler, H. D. Mason, Y. Wilson, L. Cowking, T. A. Bramley and B. Byrne, unpublished; Tijssen et al., 1997, van Dieten et al., 1999), it is not clear whether such effects are evident in vivo in women and this may be an artefactual effect of study design. There is also extensive in vitro and in vivo evidence for the suppressive effects of GnSAF on GnRH self-priming (Messinis and Templeton, 1991; 


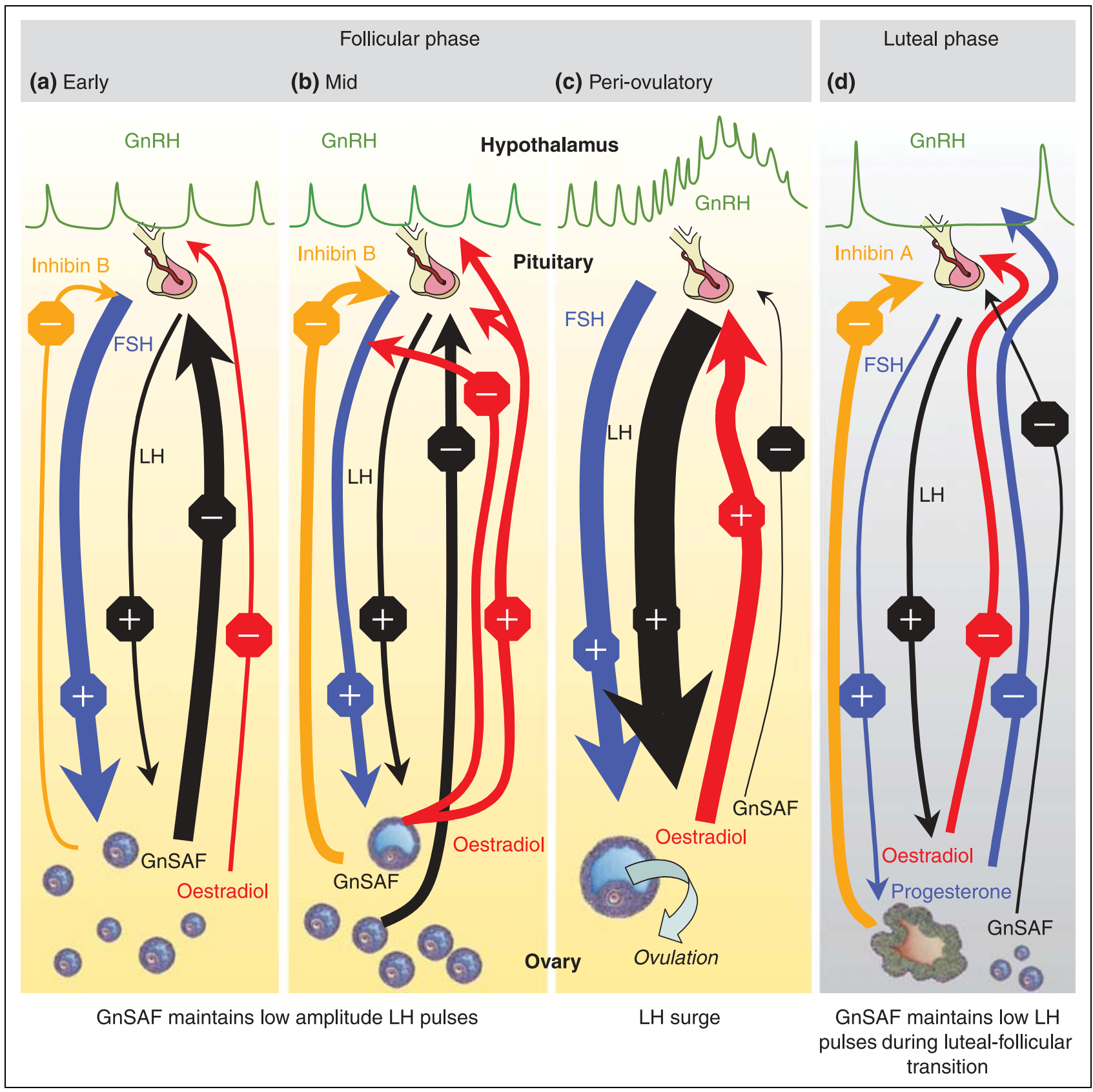

Fig. 4. Outline of the endocrine regulation of the menstrual cycle. The thickness of arrows is indicative of circulating hormone concentrations and their relative effect, as indicated by + (positive) or - (negative) signs. (a) Early follicular phase: FSH drives follicular development, with oestradiol and high concentrations of gonadotrophin surge-attenuating factor (GnSAF) exerting negative feedback on the amplitude of $\mathrm{LH}$ pulses, driven by GnRH pulses at a rate $>1$ per h. (b) Mid-follicular phase: inhibin B or oestradiol inhibit FSH release, leading to selection of the dominant follicle. As the subordinate follicles become atretic GnSAF begins to decrease from peak concentrations although GnSAF continues to moderate $\mathrm{LH}$ pulse amplitude and therefore oestradiol production. GnRH pulses are approximately circhoral. (c) Periovulatory period: high concentrations of oestradiol, stimulating high frequency GnRH pulses (up to 1 pulse every $15 \mathrm{~min}$ ) easily overcome negligible GnSAF antagonism. Prolonged oestradiol positive feedback in the presence of a small increase in progesterone may lead to a GnRH surge (as occurs in non-human primates), events leading to the LH surge and ovulation. (d) Luteal phase: the hypothalamus-pituitary-ovary axis is clamped with negative feedback from oestradiol, progesterone and inhibin A produced by the corpus luteum. GnRH pulse frequency decreases to approximately one pulse every $4 \mathrm{~h}$, whereas LH pulse amplitude is initially high. Low concentrations of GnSAF are released from quiescent small follicles. At the end of the luteal phase the inter-cycle FSH increase begins the next cycle of folliculogenesis and GnSAF production increases as a new cohort of small follicles begin to grow rapidly. During the luteal-follicular transition GnSAF may reduce LH pulse amplitude as GnRH pulse frequency increases. 
Koppenaal et al., 1992, 1993; Fowler et al., 1994b; Byrne et al., 1996). This effect is not due to occupancy of the pituitary $\mathrm{GnRH}$ receptor, but involves blockade of several second messenger mechanisms (Fowler et al., 1994c; Tijssen et al., 1997). A preliminary study indicates that the as yet unidentified GnSAF receptor may act via the C-AMP signal transduction pathway (Helder et al., 1997). Therefore, it may be hypothesized that GnSAF will antagonize the effects of GnRH on the pituitary by interfering with the positive feedback effects of oestradiol and reducing post-GnRH receptor second messenger signalling to prevent GnRH self-priming and reduce the resulting amplitude of $\mathrm{LH}$ pulses.

\section{A working hypothesis for the role of GnSAF in regulating $\mathrm{LH}$ secretion}

A schematic diagram for the potential role of GnSAF in the endocrine regulation of the menstrual cycle and LH surge is shown in Fig. 4. Early in the follicular phase (Fig. 4a), small growing follicles, stimulated by $\mathrm{FSH}$, produce high concentrations of GnSAF and small quantities of oestradiol, the GnSAF in particular having a negative feedback effect on pituitary responsiveness to $\mathrm{GnRH}$ and thus maintaining low concentrations of $\mathrm{LH}$ and keeping $\mathrm{LH}$ pulse amplitude low. As the follicles grow, inhibin $B$ secretion peaks during the midfollicular phase (Fig. 4b). Inhibin B or oestradiol cause FSH secretion to decline, resulting in the selection and further growth of the dominant follicle, but atresia of subordinate follicles. At this stage oestradiol begins to switch to positive feedback, but this is antagonized to an extent by continuing GnSAF production, resulting in the maintenance of low concentrations of $\mathrm{LH}$ and small LH pulses. Nevertheless, increasing GnRH pulse frequency is occurring, slowly rising from the roughly circhoral pulses of the early-mid follicular phase. Explosive dominant follicle growth into the preovulatory period (Fig. 4c) is matched by a large increase in circulating oestradiol and atresia of the subordinate follicles, resulting in a decrease in GnSAF production. At this time falling GnSAF may act permissively in terms of follicular steroidogenesis by allowing higher $\mathrm{LH}$ pulse amplitude. The oestradiol also has hypothalamic effects, stimulating GnRH neurones (Herbison, 1998). The positive feedback effects of oestradiol on the hypothalamus and pituitary become predominant and rapid GnRH pulses, possibly augmented by GnRH selfpriming or even a $\mathrm{GnRH}$ surge, occur. There is very little, if any, GnSAF remaining in the circulation by this stage to inhibit pituitary responsiveness to GnRH and the LH surge results, followed by ovulation some $36 \mathrm{~h}$ later. During the luteal phase (Fig. 4d), the corpus luteum maintains pituitary 'clamping' via progesterone and inhibin A signalling and the next cohort of small follicles is relatively quiescent. The role of GnSAF in regulating $\mathrm{LH}$ secretion is probably negligible at this time. However, towards the end of the luteal phase, failure of the corpus luteum and the resulting inter-cycle FSH increase stimulates follicular growth and GnSAF production. The latter will again begin to inhibit $\mathrm{LH}$ pulse amplitude, allowing a more favourable environment for follicular development.

It must be noted that this tentative scheme requires validation by carefully designed studies once the GnSAF molecule has been fully characterized.

\section{Conclusions}

GnSAF is a non-steroidal, non-inhibin, ovarian hormone, secreted by the granulosa cell in response to FSH. It has the specific effect of negatively regulating the release of $\mathrm{GnRH}$-induced $\mathrm{LH}$, therefore having a probable role in the regulation of the magnitude of $\mathrm{LH}$ pulses, coordinating the $\mathrm{LH}$ signal with follicular development and steroidogenesis in women and other mammals. In terms of the timing and magnitude of the preovulatory LH surge, GnSAF probably has far less direct effect than previously thought. The study of the role and importance of GnSAF has been hampered by the extreme difficulty experienced in definitively characterizing the bioactive molecule. Nevertheless, substantial progress in identifying the nature of $\mathrm{GnSAF}$ and its putative role in the regulation of the $\mathrm{LH}$ surge has been made in the last 20 years. Furthermore, recent progress by our group indicates that GnSAF may soon be identified. This would resolve problems associated with the absence of an immunoassay to measure circulating and follicular fluid GnSAF titres and the lack of homogeneous GnSAF preparations for physiological investigation. It is hoped that exciting studies to establish the importance and potential application of GnSAF in the regulation of reproduction in the female will be possible in the near future.

The Aberdeen GnSAF work has been supported by the BBSRC, MRC, SOHHD, ACTR, Royal Society, Scottish Hospital Endowments Research Trust (Mrs Jean V Baxter Fellowship), AresSerono Ltd (UK and Spain) and the University of Aberdeen.

\section{References}

Baerwald AR, Adams PG and Pierson RA (2003a) A new model for ovarian follicular development during the human menstrual cycle Fertility and Sterility 80 116-122

Baerwald AR, Adams PG and Pierson RA (2003b) Characterisation of ovarian follicular wave dynamics in women Biology of Reproduction 69 1023-1031

Bassettt SG and Zeleznik AJ (1990) Acute suppression of FSH secretion by oestradiol in the ovariectomised rhesus monkey Journal of Reproduction and Fertility $\mathbf{8 8} 441-446$

Burger HG, Groome NP and Robertson DM (1998) Both inhibin A and $B$ respond to exogenous follicle-stimulating hormone in the follicular phase of the human menstrual cycle Journal of Clinical Endocrinology and Metabolism 83 4167-4169 
Byrne B, Fowler PA, Messinis IE and Templeton A (1993) Gonadotrophin surge-attenuating factor secretion varies during the follicular phase of the menstrual cycle of spontaneously cycling women Journal of Endocrinology 139 Supplement P53

Byrne B, Fowler PA, Fraser M, Culler M and Templeton A (1995) GnSAF bioactivity in serum from superovulated women is not blocked by inhibin antibody Biology of Reproduction 52 88-95

Byrne B, Fowler PA and Templeton A (1996) Role of progesterone and nonsteroidal ovarian factors in regulating gonadotropin-releasing hormone self-priming in vitro. Journal of Clinical Endocrinology and Metabolism 81 1454-1459

Chabbert Buffet N, Djakoure C, Christin Maitre S and Bouchard P (1998) Regulation of the human menstrual cycle Frontiers in Neuroendocrinology 19 151-186

Clarke IJ (1995) Evidence that the switch from negative to positive feedback at the levels of the pituitary gland is an important timing event for the onset of the preovulatory surge in the ewe Journal of Endocrinology 145 271-282

Danforth DR and Cheng CY (1995) Purification of a candidate gonadotropin surge inhibiting factor from porcine follicular fluid Endocrinology 136 1658-1665

Danforth DR, Sinosich MJ, Anderson TL, Cheng CY, Bardin CW and Hodgen GD (1987) Identification of gonadotropin surge-inhibiting factor (GnSIF) in follicular fluid and its differentiation from inhibin Biology of Reproduction 37 1075-1082

van Dieten JAMJ, Helder MN, van den Oever C and de Koning J (1999) Non-steroidal factors in bovine follicular fluid inhibit or facilitate the action of pulsatile administration of $\mathrm{GnRH}$ on $\mathrm{LH}$ release in the female rat Journal of Endocrinology 161 237-243

Farnworth PG, Robertson DM, de Kretser DM and Burger HG (1988) Effects of $31 \mathrm{kDa}$ bovine inhibin on $\mathrm{FSH}$ and $\mathrm{LH}$ in rat pituitary cells in vitro: antagonism of gonadotrophin-releasing hormone agonists Journal of Endocrinology 119 233-241

Ferraretti AP, Garcia JE, Acosta AA and Jones G (1983) Serum luteinising hormone during ovulation induction with human menopausal gonadotrophin for in vitro fertilization in normally menstruating women Fertility and Sterility $\mathbf{4 0} 742-747$

Fowler PA and Mason HD (2000) Human granulosa cells secrete gonadotrophin surge-attenuating factor (GnSAF) bioactivity acutely in response to FSH in vitro. Journal of Endocrinology 164 Supplement P243

Fowler PA and Price C (1997) Follicle-stimulating hormone stimulates circulating gonadotropin surge-attenuating/inhibiting factor bioactivity in cows Biology of Reproduction 57 278-285

Fowler PA and Templeton A (1996) The nature and function of putative gonadotropin surge-attenuating/inhibiting factor (GnSAF/IF) Endocrine Reviews 17 103-120

Fowler PA, Messinis IE and Templeton AA (1990) Inhibition of LHRHinduced $\mathrm{LH}$ and $\mathrm{FSH}$ release by gonadotrophin surge-attenuating factor (GnSAF) from human follicular fluid Journal of Reproduction and Fertility 90 594-597

Fowler PA, Cunningham P, Fraser M, McGregor F, Byrne B, Pappa A, Messinis IE and Templeton A (1994a) Circulating gonadotrophin surge-attenuating factor from superovulated women suppresses in vitro gonadotrophin releasing-hormone self-priming Journal of Endocrinology 143 45-54

Fowler PA, Fraser M, Cunningham P, Knight PG, Byrne B, McLaughlin E, Wardle PG, Hull MGR and Templeton A (1994b) Higher gonadotrophin surge-attenuating factor (GnSAF) bioactivity is found in small follicles from superovulated women Journal of Endocrinology 143 33-44

Fowler PA, Bramley TA, MacGregor F and Templeton A (1994c) Does GnSAF act through the pituitary protein kinase $C$ pathway? Journal of Reproduction and Fertility Abstract Series 1340

Fowler PA, Fahy U, Culler MD, Knight PG, Wardle PG, McLaughlin EA, Cunningham P, Fraser M, Hull MGR and Templeton A (1995) GnSAF bioactivity is present in follicular fluid from naturally cycling women Human Reproduction 10 68-74

Fowler PA, Sorsa T, Harris WT, Knight PG and Mason HD (2001) Relationship between follicle size and gonadotrophin surge-attenuating factor (GnSAF) bioactivity during spontaneous cycles in women Human Reproduction 16 1353-1358

Fowler PA, Mason HD, Melvin WT, Wilson Y, Cash P, Sorsa-Lesley T and Harris W (2002) A 60-66 kDa protein with gonadotrophin surgeattenuating factor (GnSAF) bioactivity is produced by human ovarian granulosa cells Molecular Human Reproduction 8 823-832

Gill S, Lavoie HB, Bo-Abbas Y and Hall JE (2002) Negative feedback effects of gonadal steroids are preserved with aging in post-menopausal women Journal of Clinical Endocrinology and Metabolism 87 2297-2302

Ginther OJ, Beg MA, Bergfelt DR, Donadeu FX and Kot K (2001) Follicle selection in monovular species Biology of Reproduction $\mathbf{6 5}$ 638-647

Gosselin N, Price CA, Roy R and Carriere PD (2000) Decreased LH pulsatility during initiation of gonadotropin superovulation treatment in the cow: evidence for negative feedback other than oestradiol and progesterone Theriogenology 54 507-521

Groome NP, Illingworth PJ, O'Brien M, Pai R, Rodger FE, Mather JP and McNeilly AS (1996) Measurement of dimeric inhibin B throughout the human menstrual cycle Journal of Clinical Endocrinology and Metabolism 81 1401-1405

Helder MN, van Eersel SE, van Heurn JW and de Koning J (1997) Gonadotrophin surge-inhibiting factor inhibits GnRH-stimulated mitogenactivated protein kinase activation Human Reproduction 12 Supplement $167-68$

Herbison AE (1998) Multimodal influence of estrogen upon gonadotropinreleasing hormone neurons Endocrine Reviews 19 302-330

De Jong FH, Welschen R, Hermans WP, Smith SD and van der Molen HJ (1979) Effects of factors from ovarian follicular fluid and Sertoli cell culture medium on in vivo and in vitro release of pituitary gonadotrophins in the rat: an evaluation of systems for the assay of inhibin Journal of Reproduction and Fertility 26 47-59

Karsch FJ, Weick RF, Bulter WR, Dierschke DJ, Krey LC, Weiss G, Hotchkiss J, Yamaji T and Knobil E (1973) Induced LH surges in the rhesus monkey: strength-duration characteristics of the oestrogen stimulus Endocrinology 92 1740-1747

Kita M, Taii S, Kataoka N, Shimatsu A, Nakao K and Mori T (1994) Changes of gonadotrophin surge inhibiting/attenuating factor activity in pig follicular fluid in relation to follicle size Journal of Reproduction and Fertility 101 59-66

De Koning J, Lambalk CB, Helmerhorst FM and Helder MN (2001) Is GnRH self-priming an obligatory feature of the reproductive cycle? Human Reproduction 16 209-214

Koppenaal DW, Tijssen AMI and de Koning J (1992) The effect of gonadotrophin surge-inhibiting factor on the self-priming action of gonadotrophin-releasing hormone in female rats in vitro. Journal of Endocrinology 134 427-436

Koppenaal DW, van Dieten JAMJ, Tijssen AMI and de Koning J (1993) Induction of the gonadotrophin surge-inhibiting factor by FSH and its elimination: a sex difference in the efficacy of the priming effect of gonadotrophin-releasing hormone on the rat pituitary gland Journal of Endocrinology 138 191-201

Littman BA and Hodgen GD (1984) Human menopausal gonadotrophin stimulation in monkeys: blockade of the luteinising hormone surge by a highly transient ovarian factor Fertility and Sterility 41 440-447

McCartney CR, Gingrich MB, Hu Y, Evans WS and Marshall JC (2002) Hypothalamic regulation of cyclic ovulation: evidence that the increase in gonadotropin-releasing hormone pulse frequency during the follicular phase reflects the gradual loss of the restraining effects of progesterone Journal of Clinical Endocrinology and Metabolism 87 2194-2200

McNatty KP (1981) Hormonal correlates of follicular development in the human ovary Australian Journal of Biological Science 34 249-268

Magoffin DA and Jakimiuk AJ (1997) Inhibin A, inhibin B and activin A in the follicular fluid of regularly cycling women Human Reproduction 12 1714-1719

Marshall JC, Eagleson CA and McCartney CR (2001) Hypothalamic dysfunction Molecular and Cellular Endocrinology 183 29-32

Martin KA, Welt CK, Taylor AE, Smith JA, Crowley WF, Jr and Hall JE (1998) Is GnRH reduced at the midcycle surge in the human? Neuroendocrinology 67 363-369 
Martinez F, Knight PG, Groome NP, Barri PN, Coroleu V, Tur R and Fowler PA (2002) Circulating gonadotrophin surge-attenuating factor (GnSAF), inhibin-A and inhibin-B are reduced in women with previous spontaneous luteinization Human Reproduction 17 634-640

Messinis IE and Templeton A (1986) The effect of pulsatile follicle stimulating hormone on endogenous luteinizing hormone surge in women Clinical Endocrinology 25 633-640

Messinis IE and Templeton A (1991) Attenuation of gonadotrophin release and reserve in superovulated women by gonadotrophin surge attenuating factor Clinical Endocrinology 34 259-263

Messinis IE, Hirsch P and Templeton A (1991) Follicle stimulating hormone stimulates the production of gonadotrophin surge attenuating factor (GnSAF) in vivo. Clinical Endocrinology 35 403-407

Messinis IE, Lolis D, Papadopoulos L, Tsahalina T, Papanikolaou N, Seferiadis K and Templeton AA (1993a) Effect of varying concentrations of follicle stimulating hormone on the production of gonadotrophin surge attenuating factor (GnSAF) in women Clinical Endocrinology 39 $45-50$

Messinis IE, Koutsoyiannis D, Milingos S, Tsahalina E, Seferiadis K, Lolis D and Templeton A (1993b) Changes in pituitary response to $\mathrm{GnRH}$ during the luteal-follicular transition of the human menstrual cycle Clinical Endocrinology 38 159-163

Messinis IE, Lolis D, Zikopoulos K, Tsahalina E, Seferiadis K and Templeton AA (1994a) Effect of an increase in FSH on the production of gonadotrophin surge-attenuating factor in women Journal of Reproduction and Fertility 101 689-695

Messinis IE, Lolis D, Papastergiopoulou L, Milingos S, Tsahalina E, Seferiadis K and Templeton AA (1994b) Effect of follicle stimulating hormone treatment on the pituitary response to luteinizing hormonereleasing hormone in post-menopausal women Human Reproduction 9 241-244

Messinis IE, Lolis D, Zikopoulos S, Milingos S, Kollios G, Seferiadis K and Templeton AA (1996) Effect of follicle stimulating hormone or human chorionic gonadotrophin treatment on the production of gondaotrophin surge attenuating factor (GnSAF) during the luteal phase of the human menstrual cycle Clinical Endocrinology 44 169-175

Mroueh JM, Arbogast LK, Fowler PA, Templeton A, Friedman CI and Danforth DR (1996) Identification of gonadotropin surge-inhibiting factor (GnSIF)/attenuin in human follicular fluid Human Reproduction 11 101-107

Muttukrishna S and Knight PG (1990) Effects of crude and highly purified bovine inhibin $(M, 32000)$ form on gonadotrophin production by ovine pituitary cells in vitro: inhibin enhances gonadotrophinreleasing hormone-induced release of LH Journal of Endocrinology 127 149-159

Ordog T, Goldsmith JR, Chen M-D, Connaughton MA, Hotchkiss J and Knobil E (1998) On the mechanism of the positive feedback action of estradiol on luteinizing hormone secretion in the Rhesus monkey Journal of Clinical Endocrinology and Metabolism 83 4047-4053

Pappa A, Seferiadis K, Fotsis T, Shevchenko A, Marselos M, Tsolas $O$ and Messinis IE (1999) Identification of a candidate gonadotrophin surge attenuating factor from human follicular fluid Human Reproduction $\mathbf{1 4}$ $1449-1456$

Park SJ, Goldsmith LT and Weiss G (2002) Age-related changes in the regulation of luteinizing hormone secretion by estrogen in women Experimental Biology and Medicine 227 455-464

Pau K-Y, Merria M, Hess DL and Spies HG (1993) Preovulatory gonadotropin-releasing hormone surge in ovarian-intact Rhesus Macaques Endocrinology 133 1650-1656
Schenken RS, Anderson WH and Hodgen GD (1984) Follicle-stimulating hormone increases ovarian vein nonsteroidal factors with gonadotropininhibiting activity Fertility and Sterility $\mathbf{4 2}$ 785-790

Shoham Z, Schachter M, Loumaye E, Weissman A, MacNamee M and Inslet V (1995) The luteinizing hormone surge - the final stage in ovulation induction: modern aspects of ovulation triggering Fertility and Sterility $64237-251$

Skinner DC, Harris TG and Evans NP (2000) Duration and amplitude of the luteal phase progesterone increment times and the estradiol-induced luteinizing hormone surge in ewes Biology of Reproduction 631135 1142

Sopelak VM and Hodgen GD (1984) Blockade of the estrogen-induced luteinizing hormone surge in monkeys: a nonsteroidal, antigenic factor in porcine follicular fluid Fertility and Sterility 41 108-113

Sorsa T, Fowler PA and Harris W (2001) Single chain antibody fragments (ScFv) against GnSAF recognise both its activity and clones from a human ovary cDNA library Reproduction Abstract Services 2727

Sorsa-Leslie T, Harris WJ and Fowler PA (2002) Engineering of single chain antibodies selected from a phage display library into human IgGs that recognise gonadotrophin surge-attenuating factor (GnSAF) bioactivity Endocrine Abstracts 3 P231

Sorsa-Leslie T, Harris WJ, Mason HD and Fowler PA (2003) Immunopurification of gonadotrophin surge-attenuating factor (GnSAF) bioactivity Endocrine Abstracts 5 P209

Sullivan MW, Stewart-Akers A, Krasnow JS, Berga L and Zeleznik AJ (1999) Ovarian responses in women to recombinant follicle-stimulating hormone and luteinizing hormone $(\mathrm{LH})$ : a role for $\mathrm{LH}$ in the final stages of follicular maturation Endocrinology 84 228-232

Taylor AE, Whitney H, Hall JE, Martin K and Crowley WF (1995) Midcycle levels of sex steroids are sufficient to recreate the follicle-stimulating hormone but not the luteinising hormone midcycle surge: evidence for the contribution of other ovarian factors to the surge in normal women Journal of Clinical Endocrinology and Metabolism 80 1541-1547

Tijssen AMI, Helder MN, Chu Z W and de Koning J (1997) Intracellular antagonistic interaction between $\mathrm{GnRH}$ and gonadotrophin surgeinhibiting/attenuating factor bioactivity downstream of second messengers involved in the self-priming process Journal of Reproduction and Fertility 111 235-242

Tio S, Koppenaal D, Bardin CW and Cheng CY (1994) Purification of gonadotropin surge-inhibiting factor from Sertoli cell-enriched culture medium Biochemical and Biophysical Research Communications 199 1229-1236

Welt CK, Smith ZA, Pauler DK and Hall JE (2001) Differential regulation of inhibin-A and inhibin-B by luteinising hormone, follicle-stimulating hormone, and stage of follicle development Journal of Clinical Endocrinology and Metabolism 86 2531-2537

Welt CK, Pagan YL, Smith PC, Rado KB and Hall JE (2003) Control of follicle-stimulating hormone by estradiol and the inhibins: critical role of estradiol at the hypothalamus during the luteal-follicular transition Journal of Clinical Endocrinology and Metabolism 88 1766-1771

Westergaard LW, Christensen IJ and McNatty KP (1986) Steroid levels in ovarian follicular fluid related to follicle size and health status during normal menstrual cycle in women Human Reproduction $1227-232$

Yamaji T, Dierchke DJ, Hotchkiss J, Bhattacharya AN, Surve AH and Knobil E (1971) Estrogen induction of LH release in the rhesus monkey Endocrinology 89 1034-1041

Zeleznik AJ and Benyo DF (1994) Control of follicular development, corpus luteum function, and the recognition of pregnancy in higher primates. In The Physiology of Reproduction pp 751-782 Eds E Knobil and JD Neill. Raven Press, New York 